\title{
OPEN MUSEUM AS A TOOL FOR CULTURE SUSTAINABILITY: PRAMBANAN TEMPLE STUDY CASE
}

\author{
Munadjat Wardoyo dan Rilla Oktoviami Zef \\ School of Architecture, Planning, and Policy Development \\ Institute Technology of Bandung, Jawa Barat \\ E-mail: munadjat.wardoyo@gmail.com
}

\begin{abstract}
The rapid city developments are certainly through planning which will affect the development directly or indirectly. So it is very important to take care of historical buildings or other cultural heritage. A cultural heritage is certainly a major attraction of heritage tourism in a city that has historical heritage. In this discussion it was also stated that the open museum is an effective tool for maintaining urban heritage, preserving history and culture, and encouraging sustainable tourism in an area that relies on heritgae tourism in urban areas. Prambanan Temple is one of the cultural heritage areas included in the UNESCO world heritage site list, located in urban areas and vulnerable to changes both in terms of rapid urban development. This study uses a non-interactive qualitative method, namely by analyzing through existing documents. In addition, this research was also supported by literature review related to the open museum in the city of Mecca which could be used as a guide for application to further strengthen the sustainability of Prambanan Temple from the impact of urban development and the development of heritage toursim. Literature on urban heritage tourism, cultural heritage sites, and sustainable development is a support in understanding the urgency of research issues and drawing conclusions to plan the Prambanan Temple as an Open Musuem. Open museums do not just become a label but also apply certain conditions so that the building of cultural heritage can continue to be maintained its authenticity in line with urban development and heritage tourism.
\end{abstract}

Key words: Open Museum; Sustainable Tourism; Culture Sustainability

\section{OPEN MUSEUM SEBAGAI ALAT UNTUK CULTURE SUSTAINABILITY}

\begin{abstract}
ABSTRAK. Sebuah kota ataupun daerah yang di dalamnya terdapat warisan budaya atau cultural heritage tidak akan terhindar dari pesatnya perkembangan. Perkembangan tersebut tentunya melalui perencanaan yang akan mempengaruhi perkembangan langsung ataupun tidak langsung. Sehingga sangat penting untuk melakukan pemeliharan terhadap bangunan-bangunan bersejarah ataupun warisan budaya lainnya. Suatu warisan budaya tentu merupakan ketertarikan utama dari heritage tourism sebuah kota yang memiliki peninggalan bersejarah. Pada pembahasan ini juga dikemukakan bahwa open museum merupakan alat yang efektif untuk memelihara urban heritage, mempertahankan sejarah dan budaya, serta mendorong sustainable tourism pada suatu wilayah yang mengandalkan heritgae tourism di perkotaan. Candi Prambanan merupakan salah satu kawasan cagar budaya yang termasuk dalam daftar world heritage site UNESCO, berada di wilayah perkotaan dan rentan terhadap perubahan baik dari segi perkembangan perkotaan yang semakin pesat. Penelitian ini menggunakan metode kualitatif non-interaktif, yaitu dengan menganalisis melalui dokumen-dokumen yang ada. Selin itu penelitian ini juga didukung dengan literatur review yang terkait open museum di Kota Mekah yang bisa dijadikan panduan untuk penerapan untuk semakin memperkuat keberlangsungan Candi Prambanan dari dampak perkembangan perkotaan dan berkembangnya heritage toursim. Literatur mengenai urban heritage tourism, cultural heritage site, dan sustainable development menjadi penunjang dalam pemahaman urgensi permasalahan penelitian dan pengambilan kesimpulan untuk merencanakan Candi Prambanan sebagai Open Musuem Sehingga penelitian ini menyimpulkan bahwa open museum pada kawasan dan bangunan cagar budaya sangat diperlukan, terutama Candi Prambanan. Open museum tidak hanya menjadi sekedar label tetapi juga menerapkan kondisi-kondisi tertentu sehingga bangunan cagar budaya dapat terus terjaga keasliannya seiring dengan perkembangan perkotaan dan heritage tourism.
\end{abstract}

Kata kunci: Museum Terbuka; Pariwisata Berkelanjutan; Keberlanjutan Budaya

\section{INTRODUCTION}

The UNESCO cultural committee in Paris publishes a list of publications about world cultural heritage sites and lists of intangible world cultural heritages (intangible cultural heritage). With this, displayed sites that are listed have extraordinary value for human civilization. In addition, everyone in the world is responsible for protecting and preserving these sites (Santa-Cruz \& López-Guzmán, 2017 pg.113) and (Canale, Simone, Maio, \& Parenti, 2019 pg.115). The publication of UNESCO's list of world heritage is a way to support, preserve, and transmit to the next generation through historical and artistic perspectives (Saipradist \& Staiff, 2008, pg.216). In some studies began to suggest sites listed in the UNESCO world heritage list have benefits for tourist attractions (Yang \& Lin, 2014, pg.803) (Patuelli, Mussoni, \& Candela, 2014, pg. 99) and (Su \& Lin, 2014, pg 50), while other studies has no positive influence or impact in relation to world cultural heritage (Cellini, 2011 pg.452) and (Cuccia, Guccio, \& Rizzo, 2016 pg.496). On tourist destination issues the number of tourists that can be given damage to cultural or natural sites (Canale, Simone, Maio, \& Parenti, 2019 pg 117). 
Indonesia has regulations regarding which cultural heritage, cultural heritage itself is defined as artifacts made by humans, both those that can be moved or cannot be moved, individually or in groups, or the remaining parts, which are at least 50 years old. In addition, natural objects that are considered to have significant value in history, culture, and science (Presidential Regulation of the Republic of Indonesia number 5/1992 related to cultural heritage) in (Darmawan \& Enis, 2016, pg 714). The concept of open air museum as a tool for conservation of heritage buildings and cultural values is also planned to be applied to The Historical Peninsula in Istanbul (Durhan \& Özgüven, 2013, pg.184) and has been implemented in Kizhi as an open air museum in Russia (Kisternaya \& Kozlov , 2012, pg.576). Indonesia which has a heritage building registered with UNESCO is Prambanan Temple which is also one of the popular tourist destinations on the island of Java besides Borobudur Temple. Prambanan Temple, which is located geographically not far from urban or urban civilization, is one of the other vulnerability factors besides its appeal as a tourist destination. T The impact of tourism which continues to grow, of course, is directly related to the preservation of cultural heritage buildings of the temple itself. Besides that overlapping stakeholders also become a problem in planning the protection of Prambanan Temple as a world heritage residing in Indonesia. Therefore, this study describes the importance of planning the conservation and protection of the originality of Prambanan Temple through the concept of the open air museum. This research uses a non-interactive qualitative method and literature review. So with this research it is expected that every stakeholder responsible for the Prambanan Temple can provide the best and most sustainable protection to Prambanan Temple which is also a cultural heritage building recognized throughout the world and one of Indonesia's famous tourist attractions abroad.

According to the International Council of Museums in (Shehata \& Mostafa, 2017pg 364) the museum is an educational, cultural and entertainment institution that is unprofitable that serves the community through the preservation, exhibition, and maintenance of human heritage and its environment to the purpose of education, study, and pleasure (pleasure). Gurian in (Shehata \& Mostafa, 2017pg 364) defines 5 types of museums that are classified according to their use and function which are described as follows:

- Object-Centered: treasure based or museum art that presents objects without context

- Narrative: only displays objects that match the story/ story. Usually widely used by all types of multimedia

- Client-Centered: concentrated in individuals and small social groups such as children and families.
This depends on interactive exhibition techniques and role playing

- Community focused: it looks like a museum but often becomes the center or center of a multi-agency community

- National: usually the physical appearance of a country's national aspirations

Recently, it can be said that the existing museum is a mixture of several types of museums above. Apart from the types of museums identified by Gurian in (Shehata \& Mostafa, 2017 pg.364), museums in general can also be distinguished in several other categories, as can be explained in the table below:

\section{Table 1. Type and Classification of Museums}

\begin{tabular}{ll}
\hline \multicolumn{1}{c}{ Museum Type } & \multicolumn{1}{c}{ Museum Classification } \\
\hline Museum based on ownership & $\begin{array}{l}\text { Public, non-profitable } \\
\text { organizations, or charity } \\
\text { / charity ownership }\end{array}$ \\
Museums based on their size & Small, medium, large \\
The museum is based on its & Artistic, scientific, historic, \\
collection & public and special \\
Museums based on other & Closed, open, and virtual \\
physical types & \\
Sumber: (Shehata \& Mostafa, & \\
2017) & \\
\hline
\end{tabular}

On these days, there are thousands of open museums of various types and statuses. The Association of European Open Air Museums in (Shehata \& Mostafa, 2017, pg.364) defines the Open Air Museum as an open-air scientific collection of various types of structures, which are constructional and functional entities, describing residential, residential, economic and technological patterns. Open museums can be built in the first two ways, namely by making mockups from real sites by referring to the old buildings. The second and most common method is to use old buildings and urban areas as a frame to load the presentation function of the building itself.

The role of cities in making the Open Museum is closely related to urban heritage tourism. Urban heritage tourism itself is a concept of tourism which has been expressed in recent years in major cities throughout the world, which utilize the built and natural environment of a city that also has its own historical value (Widyastuty, 2011, pg 65). Culture is one of the main tourist objects that are relied on by each nation, which is about three decades ago where tourists began to be interested in the legacies of the past that could be in the form of historic city buildings in each region (Setiawan, 2010, pg.700). According to (Demas, 2009) deep cultural or cultural resources (Shehata \& Mostafa, 2017 pg. 364) can be classified through five types which can be described in the following table: 
Table 2. Cultural Resources and Classifications

\begin{tabular}{|c|c|}
\hline Cultural Resources & Classification \\
\hline Building & $\begin{array}{l}\text { Houses, hotels or similar constructions } \\
\text { that have been built to protect human } \\
\text { activities. This term also applies to } \\
\text { any construction that accommodates } \\
\text { supporting functions such as courts and } \\
\text { prisons or even homes. }\end{array}$ \\
\hline Structure & $\begin{array}{l}\text { Built to serve a different purpose as } \\
\text { opposed to building / building. The } \\
\text { structure does not accommodate } \\
\text { activities, its functions include bridges. }\end{array}$ \\
\hline Object & $\begin{array}{l}\text { This term is usually used for historic or } \\
\text { man-made objects that are small, simple, } \\
\text { and natural objects. }\end{array}$ \\
\hline Sites & $\begin{array}{l}\text { The location of the occurrence of } \\
\text { specific and major historical events. It } \\
\text { can also be a single building, ruins, or } \\
\text { even just the location of a historic event, } \\
\text { no matter the value of the surrounding } \\
\text { buildings. }\end{array}$ \\
\hline District & $\begin{array}{l}\text { The center or liaison between locations or } \\
\text { historic activities that are spread through } \\
\text { the area above the master plan. }\end{array}$ \\
\hline & Source: (Shehata \& Mostafa, 2017 pg.364) \\
\hline
\end{tabular}

In the context of urban heritage tourism, These cultural resources will bring tourists to appreciate and interpret the objects observed or presented in an area visited by the tourists. So that, in addition to functioning as a means of education and recreation for the community, these activities also serve as a means of preservation of the city's cultural wealth (Widyastuty, 2011,pg.66). The preservation then leads to the next concept of sustainable development which can be interpreted as development that meets the needs of the present without compromising the ability of future generations to meet their own needs (Robinson \& Picard, 2006, pg.1). Another concept that is also related to is sustainable urban regeneration is a process that helps reconstruct or rehabilitate urban structures / structures, revitalize the community based economy and build social capital (Demas, 2009, pg 1). Sustainable development is supported by the existence of heritage conservation which is a key factor of sustainable urban regeneration, both of which require comprehensive policies for the implementation of heritage conservation itself (especially community / community involvement) (Shehata \& Mostafa, 2017).

The discussion in the journal chosen in this paper took the case of Mecca as one of the Open Museums that was trying to be planned for its cultural sustainability. The city of Mecca is the center of the Islamic world which is the origin of the Islamic civilization that once ruled the world. The city of Mecca has all the cultural and social diversity needed to become one of the best cities in the world to live in. The city of Mecca receives around ten million visitors every year from the Islamic world and the city of Mecca also has many religious and historic locations that need to be preserved and represented (Shehata \& Mostafa, 2017) pg 369 .

The city of Mecca itself has two types of locations, first one is religious location; the second one is historic and heritage location. Besides these two locations, the city of Mecca has many old and modern museums that receive thousands of visitors every year from all over the Islamic world. Some of the museums are the Mecca Heritage Museum, Umm Al-Qura Museum, Islamic Dinar Museum, and Peace Upon You Muhammad Museum. Regarding the capacity of visitors or tourists received through Hajj and Umrah reached ten million visitors in one year with varied socio-economic backgrounds, interests and backgrounds (Shehata \& Mostafa, 2017) pg367.

Through several precedents from the sustainable cultural sites development presented in this journal, such as Darb Al-Ahmar, Luxor City, and Historic Old Rome, there are some similarities with the City of Mecca which among them is an urban part of the old city, archaeological sites integrated with other urban structures, and areas containing buildings are valuable / valuable or have value, where most are historic. So then there are some lessons that can be taken from the three examples, namely as follows:

1. Partnerships between government and non-government bodies are the basis for the success of the project.

2. Capacity building of local communities helps identify needs, problems, and priorities.

3. Involve various categories of local community assistance in the success of the project

4. Training and workshops that are often combined with practical experience of increasing the capacity of local professionals in monitoring

5. Integration between historic buildings and local urban structures can benefit both

6. Economic benefits of local communities from restoration projects for historic buildings in the vicinity

7. Integrating local communities in restoration activities helps in maintaining sustainable activities related to restored buildings

8. Combining improved agriculture with the restoration of historic buildings creating a sustainable built environment

9. Choosing a local body is important for the success of the project

10. From some of these points, then the writer in the journal suggested a number of points at the strategic level with the approach below to make some of the heritgae areas in Mecca an Open Museum:

11. Government plans to define protected historical areas, make regulations to define and protect these areas within the city of Mecca and its surroundings in accordance with Al-Mashaer protected area.

12. Involve local communities and the private sector 
through government initiatives to create a point of termination (POT) project to improve the historic area by developing both the environment and services.

13. Building a foundation for the real tourism industry through the provision of quality personnel and multimedia facilities with descriptive narratives for each location.

14. Include different locations in the Mecca City land use master plan and public transportation plans.

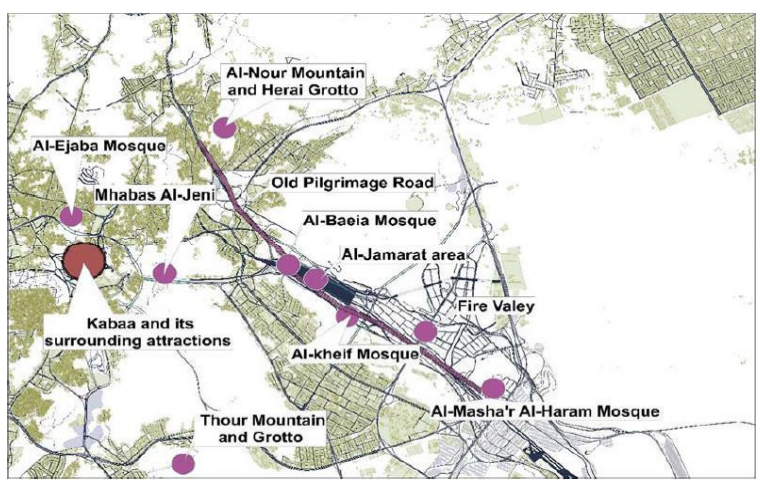

Figure 1 Track and Historical Location in the City of Mecca

Source: Shehata \& Mostafa, 2017 pg 372

At the level of action or action, the authors propose several points including the Open museum in historical locations below: Ka'aba and its surrounding (Old Makkah City); Al-Mashaer area (Arafat, Muzdalifa and Mina); Makkah Historic Mosques; Makkah Historic Mosque; Makkah Museums and palaces; Al-Nour Mountain; Thour Mountain area. The second point is that proposals for pathways that connect different historical locations will help encourage visitors to spend more time at this location. The map above illustrates suggested locations and pathways and the surrounding urban features. The fourth point is improving services in this location to match the number of visitors expected. The last point is related to cultural and folklore events around the year to extend the stay of pilgrims in Mecca, especially during the off season (Shehata \& Mostafa, 2017 pg 372).

\section{METHOD}

The research method according to (Arikunto, 1986 pg77) in (Hamdi \& Bahruddin, 2015, pg86) is a way of thinking and acting that is best prepared to conduct research in hopes of achieving the intended research objectives. This research journal that we publish uses, method: qualitative. According to (Sugiyono, 2016 pg 24) and (Creswell, 2010 pg 87) qualitative research are methods to explore and understand the meaning that some individuals or groups of people ascribe to social or human problems. This journal is a social research in which the process of finding knowledge is expected to have benefits in solving problems related to the research conducted (Chariri, 2009 pg 66).

The qualitative method outlines two methods, namely the interactive qualitative method and the noninteractive qualitative method. This journal then uses a qualitative non-interactive method (non-interactive inquiry), also known as analytical research. This research does not collect data interactively or through interaction with sources or human data sources, but the source of the data is more on existing documents (Hamdi \& Bahruddin, 2015 pg. 92). This study also uses the literature review method in published journals where the main journal that serves as a benchmark for this research is a journal entitled Open Museum as A Tool for Culture Sustainability (2016) written by Ahmed M. Abd Abd-Rahman Shehata and Mohsen Mohamed Ibrahim Mostafa.

Literature review is a form of exposure to previous research which then becomes the basis for research conducted on certain topics or fields that support. The review literature can also assist the writer in developing other related and appropriate arguments (Libraries, 2019 pg 1) (The Writing Center, 2019 pg 1). In this study an argument was developed to suggest the preservation of Prambanan Temple as one of Indonesia's recognized cultural heritage through UNESCO, by making it an 'Open Museum'.

\section{RESULTS AND DISCUSSION}

\section{Prambanan Temple as Heritage Site}

Indonesia is known as one of the countries that have a diversity of cultures, ranging from a variety of tribes, languages, traditional houses and regional dances. The diversity was formed partly because of the geographical conditions of Indonesia which is an archipelagic country consisting of various provinces. Before independence, Indonesia in several regions had kingdoms that left historic buildings, some of which can still be seen today, one of which is famous is the temple. Two temples in Indonesia have been designated as world heritage sites by UNESCO, namely Brobudur Temple and Prambanan Temple. Prambanan Temple is the largest Hindu temple in Indonesia which is located at coordinates $7^{\circ} 45^{\prime} 8^{\prime \prime}$ South Latitude and $110^{\circ} 29^{\prime} 30$ " East Longitude (Wicaksono, 2014 pg38).

Besides being known as a world heritage site by UNESCO, Prambanan Temple is also one of the famous tourist attractions in the land of Java. Prambanan Temple stands on the border of two provinces, namely Central Java Province and Yogyakarta Province, which is precisely located in Prambanan Village, whose territory is divided between Sleman and Klaten Regencies (Nieamah, 2014 
pg 52). Prambanan Temple poses a threat to earthquake natural disasters, which had previously occurred in 2006. The earthquake caused fairly severe damage to several parts of the Prambanan Temple complex, especially at the Siwa Temple (Wicaksono, 2014 pg43). As a tourist destination whose attraction is in the form of historical buildings, Prambanan Temple also enters into heritage tourism. The focus of heritage tourism is the motivation to have a diverse experience of objects or things that represent the past and present of a destination (Andago, Choe, \& Han, 2017 pg 90); (Bryce, Curran, O’Gorman, \& Taheri, 2015 pg 582); (Leong, 2016 pg191). The most important attribute of a heritage tourism is the authenticity or at least the perception of a destination itself. Authenticity can be understood as an authenticity or originality, universal values, and a crucial motivation that encourages tourists to travel to distant destinations to experience a different time (Park, Choi, \& Lee, 2019 pg 103).

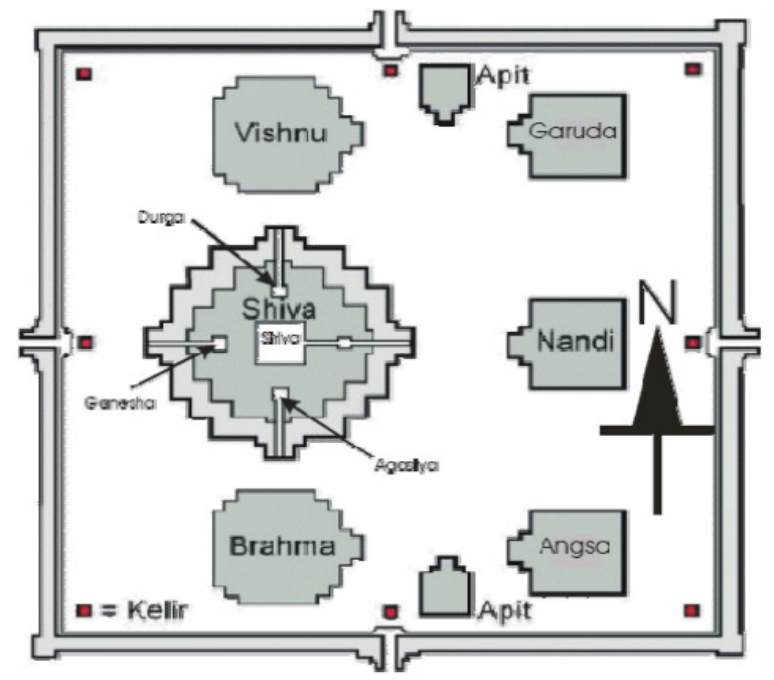

Figure 2. Prambanan Temple Complex Layout (UNESCO, 2004)

The temple complex was built during the 9th century Sanjaya Dynasty, where the layout is generally shown as shown above. The central area has three main temples based on the Hindu trinity namely Vishnu (Vishnu) facing north, Shiva (Shiva) in the middle, and Brahma in the south. The smaller temples refer to each temple as a symbol of the vehicle. The Shiva (God of Destruction) vehicle is Nandi 'the Bull'; the vehicle of Vishnu (the Creator God), namely the Eagle Garuda; and Brahma (Guardian Deity) owns a swan vehicle. Apart from temples, each temple also has a smaller courtyard. The main temple of Vishnu is located on the inner court surrounded by small temples called Pewara. These temples are historically built and presented as gifts to the King in recognition of his reign. Walls with varying heights can be seen around the complex, although some of them are in fragmentation. There are at least more than 250 small temples in the complex that is spread in the Prambanan plain (Elnashai, et al., 2007 pg.8).

\section{Reflection on the Indonesian Context}

The formation of a city in many ways can be seen as a form of cultural development in which there is an embodiment of ideology, social and technological developments that help construct a region into the city as it is today. So that it can be said that the formation of small cities is based on the knowledge, norms, beliefs, and cultural values of the people in the past (Mundardjito, 2002 pg77). Indonesia has several cultural sites which are included in the UNESCO World Heritage List including the Borobudur Temple Complex, Prambanan Temple Complex, Sangiran Ancient Human Site, and the Cultural Landscape of Bali Province: The Subak System as a Manifestation of the Tri Hita Karana Philosophy. In this paper, the discussion will focus on the cultural site of the Prambanan Temple Complex (Unesco, 2018 pg1).

The Prambanan Temple complex consists of Prambanan Temple (also called Loro Jonggrang), Sewu Temple, Bubrah Temple, and Lumbung Temple. Prambanan Temple itself is a complex consisting of 240 temples. All of the mentioned temples form Prambanan Archaeological Park and were built during the greatness of the Sailendra dynasty in Java in the 8th century. The Prambanan Temple complex is located on the border between two provinces namely Yogyakarta Province and Central Java Province on Java Island (Unesco, 2018 pg 1). On the historical side, old buildings owned by a city are able to provide an overview of past conditions. Building is a partial reality of a holistic reality that has ever existed. Therefore, building is an important element in the process of historical analysis that has information for the following generations (Martana, 2002 pg 6).

The Prambanan Temple complex has been designated as a National Cultural Property in 1998 and the National Law issued in 2010 also supports the protection and conservation of property. Management of the Prambanan Temple Complex is accommodated in a 1992 Presidential Decree which stipulated 77 hectares which included property under the ownership of the central government. This area is divided into two zones. Management of Zone 1 is carried out by the Ministry of Culture and Tourism under two different regional offices, namely the Yogyakarta and Central Java Archaeological Preservation Office. Borobudur, Prambanan and Ratu Boko Tourism Park Ltd. responsible for Zone 2 (Unesco, 2018 pg 1).

The government's efforts to improve property management are by issuing a Law in 2007 and a 2008 Government Regulation on National Spatial Planning which means that spatial planning in the World Cultural Heritage area will be prioritized. The Prambanan site has been designated as one of the national strategic areas consisting of Prambanan Temple and other related temples. Integrated management and regulations that support 
conservation are needed to ensure long-term protection of property. Some regulations in Indonesia that support conservation are Law No. 11 of 2010 concerning Cultural Heritage and KEPMENPAR No. 7 of 2016 concerning Determination of National Vital Objects (Unesco, 2018 pg 1).

The Prambanan Temple complex is one of the right examples in the development of Open Museum as a tool for culture sustainability in Indonesia, presented along with the concept of urban heritage, sustainable development and sustainable urban regeneration. The Prambanan Temple complex that contrasts with the background of the city of Yogyakarta has shaped this historical building into the formation of the Open Museum in accordance with the concepts described in the journal discussed earlier. Determination of the Prambanan Temple Complex as a Cultural Heritage and the World Cultural Heritage Site area is a form of the application of sustainable development to the heritage site.

The existence of arrangements such as the establishment of buildings as national vital objects and management of building complexes with the provisions of the Law on Cultural Heritage, make planning the development of buildings or cultural sites to be directed so that sustainability can continue to be maintained both physically and in other aspects. So that tourism activities can also continue to run with the proper conditions. This then encourages the formation of sustainable urban regeneration which will have a positive impact on the people in the region both in economic, cultural, social progress and so on.

In addition to government regulations that governing the Prambanan temple complex, other cooperation is also needed such as assistance from the local community itself. The community also needs to be included in any tourism development activities that become tourist destinations in this case the Prambanan Temple. The public needs to be informed about the tourist destinations in their area, not only unique tourist destinations, but also historical tourist destinations that are included in the list of world heritage by UNESCO. This is necessary, and another factor is added that tourists who are a world heritage are not only from domestic but also international. Insight development training needs to be supplemented with international language training, namely English. This then supports to improve the ability of the surrounding community to support and support existing programs.

\section{CONCLUSION}

Integrating local communities with historical buildings will help sustain ongoing activities around the historic buildings. Prambanan Temple, aside from being used as a protected historical building, it should be planned to establish it as an open air museum, because the background characteristics are almost similar to cases in previous review studies. Prambanan Temple, which currently stands in the area of human settlements which is currently in the progress of the technological era is a form of civilization comparison that becomes a contrast if Prambanan Temple is used as an open air museum. The concept of the open air museum can provide more support to Prambanan Temple to be able to synergize with the developments around it. The main purpose of applying the open air museum to Prambanan Temple itself is to give more emphasis to conservation so that sustainability can be realized in line with the development of the surrounding community as well as to Prambanan Temple itself.

\section{REFERENCES}

Andago, R., Choe, J., \& Han, H. (2017). Tourism in Hoi An, Vietnam: Impacts, Perceived Benefits, Community Attachment and Support for Tourism Development. International Journal of Tourism Sciences, 17, (2), 86-106.

Bryce, D., Curran, R., O’Gorman, K., \& Taheri, B. (2015). Visitors Engagement and Authenticity: Japanese Heritage Consumption. Tourism Management, 46, 571-581.

Canale, R. R., Simone, E. D., Maio, A. D., \& Parenti, B. (2019). UNESCO World Heritage Sites and Tourism Attractiveness: The Case of Italian Provinces. Land Use Policy, 85, 114-120.

Cellini, R. (2011). Is UNESCO Recognition Effective in Fostering Tourism? A Comment on Yang, Lin and Han. Tourism Management, 32, (2), 452-454.

Chariri, A. (2009). Landasan filsafat dan metode penelitian kualitatif.

Cuccia, T., Guccio, C., \& Rizzo, I. (2016). The Effects of UNESCO World Heritage List Inscription on Tourism Destinations Performance in Italian Regions. Economic Model, 53, 494-508.

Darmawan, E., \& Enis, S. A. (2016). The Changing Function of Heritage Building for Roling Tourism Planning Progress. Social and Behavioral Sciences, 227, 712-719.

Demas, M. (2009). Conservation and Management of Archaeological Sites. Los Angeles: The Getti Conservation Institute.

Durhan, S., \& Özgüven, Y. (2013). Breaking The Duality: The Historical Peninsula of Istanbul as an OpenAir Museum. Journal of Cultural Heritage, 14, (3), 183-188. 
Elnashai, A. S., Kim, S. J., Yun, G. J., \& Sidarta, D. (2007).

The Yogyakarta Earthquake of May 27, 2006. MAE Center CD Release 07-02.

Gurian, E. H. (2008). Civilizing the Museum: The Collected Writings of Elaine Heumann Gurian. Routledge.

Hamdi, A. S., \& Bahruddin, E. (2015). Metode penelitian kuantitatif aplikasi dalam pendidikan. Deepublish.

Kisternaya, M., \& Kozlov, V. (2012). Preservation of Historic Monuments in The "Kizhi" Open-Air Museum (Russian Federation). Journal of Cultural Heritage, 13, (3), 574-578.

Lee, T., Riley, M., \& Hampton, M. (2010). Conflict and Progress: Tourism Development in Korea. Annals of Tourism Research, 37, (2), 355-376.

Leong, D. (2016). Heritage or Hesitate? Preserving Authenticity in Hong Kong Tourism. International Journal of Tourism Sciences, 16, (4), 191-202.

Libraries, U. (2019, September 27). USC Libraries: Research Guides. Retrieved September 28, 2019, from USC University of Southern California: http:// libguides.usc.edu/writingguide/literaturereview

Martana, S. (2002). Preservasi Benda Bersejarah di KotaKota Indonesia Dalam Perspektif Partisipasi Masyarakat. Warta Pariwisata, 5, (3), 1-12.

Mundardjito. (2002). Research Method for Historical Urban Heritage Area. Three Days Practical Course on Planning and Design Methods for Urban Heritage.

Nieamah, K. F. (2014). Persepsi Wisatawan Mancanegara Terhadap Fasilitas Dan Pelayaan Di Candi Prambanan. Jurnal Nasional Pariwisata, 6, (1), $39-45$.

Park, E., Choi, B.-K., \& Lee, T. (2019). The Role and Dimensions of Authenticity in Heritage Tourism. Tourism Management, 74, 99-109.
Patuelli, R., Mussoni, M., \& Candela, G. (2014). Cultural Offer and Distance in a Spatial Interaction Model of Tourism. Econ. Bus. Lett, 3, (2), 96-108.

Prambanan Temple Cultural Site, http://whc.unesco.org/ en/list/642, retrieved on 8 April 2018.

Robinson, M., \& Picard, D. (2006). Tourism, Culture and Sustainable Development. Division of Cultural Policies and Intercultural Dialogue.

Saipradist, A., \& Staiff, R. (2008). Crossing The Cultural Divide: Western Visitors and Interpretation at Ayutthaya World Heritage Site, Thailand. Journal of Heritage Tourism, 2, (3), 211-224.

Santa-Cruz, F. G., \& López-Guzmán, T. (2017). Culture, Tourism and World Heritage Sites. Tourism Management Perspectives, 24, 111-116.

Setiawan, B. (2010). Preservasi, Konservasi dan Renovasi Kawasan Kota Tua Jakarta. Humaniora, 1, (2), 699-704.

Shehata, A. M.-R., \& Mostafa, M. M. (2017). Open Museums as a Tool for Culture Sustainability.

Su, Y., \& Lin, H. (2014). Analysis of International Tourist Arrivals Worldwide: The Role of World Heritage Sites. Tourism Management, 40, 46-58.

The Writing Center, U. o. (2019, September 27). The Writing Center, University of North Carolina at Chapel Hill. Retrieved September 28, 2019, from The University of North Carolina at Chapel Hill: https://writingcenter.unc.edu/tips-and-tools/ literature-reviews/

Wicaksono, A. (2014). Penentuan Pergeseran Horisontal Candi Prambanan (Doctoral dissertation, Universitas Gadjah Mada).

Widyastuty, A. S. (2011). Urban Heritage Tourism Kawasan Jalan Thamrin Denpasar Bali. Jurnal Teknik WAKTU, 9, (1), 61-71.

Yang, C., \& Lin, H. (2014). Revisiting The Relationship Between World Heritage Sites and Tourism. Tourism Economic, 20, (1), 73-86. 